\title{
1967 GORDON RESEARCH CONFERENCES
}

\begin{tabular}{|c|c|c|c|c|c|c|}
\hline & $\begin{array}{l}\text { Colby Junior College, } \\
\text { New London, } \\
\text { New Hampshire }\end{array}$ & $\begin{array}{l}\text { New Hampton } \\
\text { School, } \\
\text { New Hampton, } \\
\text { New Hampshire }\end{array}$ & $\begin{array}{l}\text { Kimball Union } \\
\text { Academy, } \\
\text { Meriden, } \\
\text { New Hampshire }\end{array}$ & $\begin{array}{l}\text { Tilton School, } \\
\text { Tilton, } \\
\text { New Hampshire }\end{array}$ & $\begin{array}{l}\text { Proctor Academy, } \\
\text { Andover, } \\
\text { New Hampshire }\end{array}$ & $\begin{array}{l}\text { Crystal Inn, } \\
\text { Crystal Mountain, } \\
\text { Washington }\end{array}$ \\
\hline June 12-16 & $\begin{array}{l}\text { Hydrocarbon } \\
\text { chemistry }\end{array}$ & $\begin{array}{l}\text { Molecular electronic } \\
\text { spectroscopy }\end{array}$ & $\begin{array}{l}\text { Science and Tech- } \\
\text { nology of bio- } \\
\text { materials }\end{array}$ & $\begin{array}{l}\text { Animal cells and } \\
\text { viruses }\end{array}$ & & \\
\hline June $19-23$ & Nuclear chemistry & Nucleic acids & Magnetic resonance & $\begin{array}{l}\text { Biochemistry and } \\
\text { agriculture }\end{array}$ & $\begin{array}{l}\text { Lasers in medicine } \\
\text { and biology }\end{array}$ & \\
\hline June $26-30$ & Catalysis & Proteins & $\begin{array}{l}\text { Cell structure and } \\
\text { metabolism }\end{array}$ & & Lipid metabolism & \\
\hline July 3-7 & Polymers & Coal science & $\begin{array}{l}\text { Coenzymes and } \\
\text { metabolic pathways }\end{array}$ & $\begin{array}{l}\text { Chemistry of hetero- } \\
\text { cyclic compounds }\end{array}$ & Lysosomes & $\begin{array}{l}\text { Environmental } \\
\text { sciences: air }\end{array}$ \\
\hline July $10-14$ & Textiles & $\begin{array}{l}\text { Statistics in } \\
\text { chemistry and } \\
\text { chemical engin- } \\
\text { eering }\end{array}$ & $\begin{array}{l}\text { Chemistry, physi- } \\
\text { ology and struc- } \\
\text { ture of bones and } \\
\text { teeth }\end{array}$ & $\begin{array}{l}\text { Chemistry and } \\
\text { physics of space }\end{array}$ & Biomathematics & $\begin{array}{l}\text { Chemistry and physies } \\
\text { of isotopes }\end{array}$ \\
\hline July $17-21$ & $\begin{array}{l}\text { Scientific information } \\
\text { problems in } \\
\text { research }\end{array}$ & Radiation chemistry & Physical metallurgy & $\begin{array}{l}\text { Chemistry and } \\
\text { physics of coatings } \\
\text { and films }\end{array}$ & $\begin{array}{l}\text { Chemistry and metal- } \\
\text { lurgy of semicon- } \\
\text { ductors }\end{array}$ & Molecular pathology \\
\hline July $24-28$ & Corrosion & $\begin{array}{l}\text { Organic reactions } \\
\text { and processes }\end{array}$ & $\begin{array}{l}\text { Chemistry at } \\
\text { interfaces }\end{array}$ & $\begin{array}{l}\text { Microbiological } \\
\text { deterioration }\end{array}$ & $\begin{array}{l}\text { Chemistry and } \\
\text { physics of paper }\end{array}$ & $\begin{array}{l}\text { Dynamics of quantum } \\
\text { solids and liquids }\end{array}$ \\
\hline July 31-Aug. 4 & Elastomers & $\begin{array}{l}\text { Steroids and other } \\
\text { natural products }\end{array}$ & $\begin{array}{l}\text { Solid state studies } \\
\text { in ceramies }\end{array}$ & $\begin{array}{l}\text { Nuclear structure } \\
\text { physics }\end{array}$ & $\begin{array}{l}\text { Chemistry and } \\
\text { physics of liquids }\end{array}$ & Medicinal chemistry \\
\hline August $7-11$ & $\begin{array}{l}\text { Separation and } \\
\text { purification }\end{array}$ & Inorganic chemistry & $\begin{array}{l}\text { Toxicology and } \\
\text { safety evaluations }\end{array}$ & $\begin{array}{l}\text { Organic photo- } \\
\text { chemistry }\end{array}$ & & Plasma physics \\
\hline August $14-18$ & Food and nutrition & Analytical chemistry & $\begin{array}{l}\text { Chemistry and } \\
\text { physics of solids }\end{array}$ & $\begin{array}{l}\text { Photonuclear } \\
\text { reactions }\end{array}$ & $*$ & $\begin{array}{l}\text { Laser interaction with } \\
\text { matter }\end{array}$ \\
\hline August $21-25$ & Ion exchange & Geochemistry & $\begin{array}{l}\text { Chemistry and } \\
\text { physies of cellular } \\
\text { materials }\end{array}$ & Thin films & * & \\
\hline $\begin{array}{r}\text { Aug. 28-Sept. } 1 \\
\text { * Week no }\end{array}$ & Cancer & Sclence of adhesion & $\begin{array}{l}\text { Chemistry of molten } \\
\text { salts }\end{array}$ & Glass & * & \\
\hline
\end{tabular}

The 1967 Gordon Research Conferences will be held in New Hampshire and Washington, between June 12 and September 1, 1967. Each conference will run from Monday to Friday each week, with meetings in the mornings and evenings. Application forms for the conferences can be obtained from W. G. Parks, Director, Gordon Research Conferences, Department of Chemistry, University of
Rhode Island, Kingston, Rhode Island 02881, and all application forms should be returned at least. two months before the date of the conference. The conferences are intended to bring together scientists for discussions in the latest developments in each field, and not for the review of known inform. ation.
A NEw journal entitled "Thin Solid Films", designed to cover all aspects of the science and technology of thin solid films, is now being published by Elsevier Publishing Company.

The thirty-second Parsons Memorial Lecture entitled "The Measurement and Control of Small Displacements", organized by the Institute of Physics and the Physical Society, will be given by Professor R. V. Jones on April 24 at the Royal Radar Establishment, Malvern. Further information can be obtained from the Meetings Officer, The Institute of Physics and the Physical Society, 47 Belgrave Square, London, S.W.1.

Erratum: In the communication entitled "Production of Oat Callus and its Susceptibility to a Plant Parasitic Nematode" by Dr. J. M. Webster (Nature, 212, 1472; 1966), the third sentence in the second paragraph should read "Glucose $(20 \mathrm{gm} / \mathrm{l}$.) or the same quantity of sucrose was used . . .".

ERratum. In the article entitled "Metabolism of Methylcarbamate Insecticides by the $\mathrm{NADPH}_{2}$-requiring Enzyme System from Houseflies" by M. Tsukamoto and J. E. Casida (Nature, 213, 49; 1967), the following corrections should be made: page 49, left-hand column, line 18, mammalian liver microsome-reduced nicotinamide adenine dinucleotide phosphate $\left(\mathrm{NADPH}_{2}\right)$ system; line 23 , the liver microsome-NADPH ${ }_{2}$ system; line 26, insect microsome-NADPH ${ }_{2}$ systems; line 37, an insect enzyme$\mathrm{NADPH}_{2}$ system. Page 49, right-hand column, line 14, the abdomen-NADPH${ }_{2}$ system; line 17, twenty-four insecticides and synergists labelled with carbon-14 were investigated. Page 50, right-hand column, line 59, the fly abdomen-NADPH ${ }_{2}$ system; line 67, O-O-dimethyl. Page 51, left-hand column, line 16, (+)-trans-chrysanthemumate; line 17, allethronyl; line 21, the fly abdomen$\mathrm{NADPH}_{2}$ system; line 25, (5-allyl-1-methoxy- . . .). Page 51 , right-hand column, line 2, chemicals; line 13, homogenate or microsomes of the resistant fly abdomen. Reference 7, The Physiology of Insecta.

\section{CORRESPONDENCE}

\section{Economic Geochemistry}

SIR,-In the note on January 7 (Nature, 213, 7; 1967), the statement that geochemistry has limited application and is still struggling for recognition is entirely erroneous.

The facts of the matter are that since the Second World War geochemical techniques have developed to the point that they are standard exploration practice in most parts of the world. At a conservative estimate, geochemical samples are being collected for prospecting purposes at a rate well in excess of 3,000,000 a year in the West, and probably nearer $10,000,000$ a year in the Soviet Union.

Mineral discoveries, wherein geochemical prospecting has played a vital role, include base metal deposits in Eastern Canada and important copper mineralizations in Central Africa and the South-west Pacific area, to mention but a few.

In the academic field, applied geochemistry is now included in any comprehensive course of training in mineral exploration and a number of research centres exist in both government establishments and in the universities at home and overseas.

The foregoing in no way implies any criticism of the technical publication you mention, which gives a most interesting description of a novel method of prospecting for use in a particular type of terrain. I am quite certain that the authors would in no way subscribe to the view expressed in that part of your note concerned with the current status of applied geochemistry in general.

Yours faithfully,

JoHN S. WEBB

Department of Geology,

Imperial College of Science and Technology. 